\title{
Effects of urinary volume on urinary concentrations of lead, $\delta$-aminolaevulinic acid, coproporphyrin, creatinine, and total solutes*
}

\section{S ARAKI}

\author{
From the Department of Public Health, Tohoku University School of Medicine, Seiryo-machi, \\ Sendai 980, Japan
}

\begin{abstract}
Urinary volume was related to urinary concentrations of lead, delta-aminolaevulinic acid (ALA), coproporphyrin (COPRO), creatinine, and total solutes in nine lead workers. On a log scale, linear relationships were found between urinary volume and the urinary concentrations. There was a certain difference in the extent of the effects of urinary volume on the urinary concentrations. For example, the concentration of creatinine was more affected by urinary volume than those of lead, ALA, and total solutes among the substances examined: similarly, the concentration of COPRO more than that of ALA. An equation was introduced to eliminate the effects of urinary volume on urinary concentrations. The effects of urinary volume on the concentrations adjusted to urinary specific gravity, osmolality, and creatinine are discussed in the light of these findings.
\end{abstract}

Urinary lead, delta-aminolaevulinic acid (ALA), and coproporphyrin (COPRO), among the indicators of the dose and effects of lead, necessitate measuring the urinary concentrations. It has been known for many years that these concentrations vary over a wide range and are inversely correlated with urinary volume throughout each 24-hour period. No factor other than urinary volume seems to play any important part in the induction of the variation. ${ }^{1}$

It remains unclear, however, to what extent those concentrations are affected by urinary volume. The excretion of lead, ALA, and total solutes was found to decrease when urinary volume was reduced: conversely, that of COPRO and creatinine was independent of urinary volume. ${ }^{2}$ This observation suggested that the effect of urinary volume is greater on the concentrations of COPRO and creatinine than on those of lead, ALA, and total solutes. A further assumption is that the extent of the effect of urinary volume can be quantitatively different among those substances.

In this paper the relationships between urinary volume and urinary concentrations of lead, ALA,

\footnotetext{
*This paper is based on part of a dissertation submitted for the degree of MSc in occupational medicine at the London School of Hygiene and Tropical Medicine, University of London.

Received 27 June 1978

Accepted 4 April 1979
}

COPRO, creatinine, and total solutes are quantitatively analysed to verify the assumption. In addition, an equation is introduced to eliminate the effects of urinary volume on urinary concentrations.

\section{Subjects and methods}

SUBJECTS

Nine male lead workers (plastics worker, lead smelter, welder, pigment maker, type founder, paint maker, galvaniser, and two stereotype founders) were admitted to hospital for diagnosis, prophylaxis, or treatment of lead poisoning. At the time of examination, six subjects had not been exposed to lead for more than three weeks; the two subjects ( 1 and 4 ) for five days; and one subject (No 9) for three days. Blood lead concentrations ranged from $0.3 \mu \mathrm{mol} / 1(7 \mu \mathrm{g} / \mathrm{dl})$ to $2.9 \mu \mathrm{mol} / 1$ $(61 \mu \mathrm{g} / \mathrm{dl})($ mean $1.7 \mu \mathrm{mol} / \mathrm{l}(35 \mu \mathrm{g} / \mathrm{dl}))$ at the time of examination. Mean age was 49 years (range 21-63). No subject showed albuminuria, and renal function tests (PSP test and Fishberg concentration test) and serum creatinine concentrations were normal or borderline in all.

COLLECTION OF URINARY SAMPLES

After maintaining their usual intake of food and water for two days, the subjects drank about 0.25 1 water each day for another two days, and were then loaded with about 31 water daily for two successive 
days. Urinary volume, specific gravity, osmolality, and concentrations of lead, ALA, COPRO, and creatinine were measured on every 24-h urinary sample. In subjects 6 and 7 the whole period of examination was five days and ten days respectively for technical reasons, and not six days.

\section{ANALYTICAL METHODS}

Lead concentrations in blood and urine were measured by atomic absorption spectrophotometry (Perkin-Elmer 403) with wet ashing, chelation by ammonium pyrrolidine dithiocarbamate, and extraction to water-saturated methyl isobutyl ketone ${ }^{3}$ : urinary ALA concentration was measured by the method of Wada et $\mathrm{al}^{\mathbf{4}}$; urinary COPRO by fluorescence spectrophotometry (Hitachi MPF-2A); creatinine by Jaffe's reaction; osmolality of urine by the freezing point depression method (Fiske Osmometer); and specific gravity of urine by refractometry (Erma Clinical Refractometer).

\section{STATISTICAL ANALYSIS}

Regression coefficients were calculated by the method of least squares from the relationship between urinary volume and urinary concentrations in each subject.

In the equation $\mathrm{Y}=\mathrm{a}-\mathrm{b} \mathrm{X}$, test for significance on the regression coefficient (b) was carried out by calculating $t_{n-2}=\frac{b-\beta}{\mathrm{SE}(\mathrm{b})}$ under the null hypothesis $\beta=0: \mathrm{n}$ was the number of observations; $\mathrm{n}-2$, degree of freedom for t-test; $\beta$, the regression coefficient in the underlying population; and SE(b), the estimated standard error of the sample regression coefficient. The difference in the regression coefficients among subjects was tested by analysis of covariance using F-test under the null hypothesis $\mathrm{H}_{0}: \beta_{1}=\beta_{2}=----\beta_{\mathrm{n}}$, where $\beta_{1}, \beta_{2},-\cdots-$ and $\beta_{\mathrm{n}}$ were regression coefficients in each underlying population. The difference in the regression coefficient between two urinary substances was tested by paired comparison using the t-test.

\section{Results}

\section{EFFECTS OF URINARY VOLUME ON URINARY CONCENTRATIONS}

Table 1 shows the daily variation in urinary concentrations of lead, ALA, COPRO, and creatinine; urinary specific gravity; urinary osmolality; and urinary volume in each subject. The urinary concentrations were inversely correlated with the corresponding urinary volume, and linear

Table 1 Daily variation in urinary concentrations of lead, ALA, coproporphyrin, and creatinine; urinary specific gravity and osmolality; and urinary volume. (Number of samples examined in parentheses)

\begin{tabular}{|c|c|c|c|c|c|c|c|c|c|}
\hline \multirow{3}{*}{ Urinary excretion } & \multicolumn{9}{|l|}{ Subjects } \\
\hline & 1 & 2 & 3 & 4 & 5 & 6 & 7 & 8 & 9 \\
\hline & (6) & (6) & $(6$ & (6) & (6) & (5) & (10) & (6) & (6) \\
\hline $\begin{array}{l}\text { Lead }(\mu \mathrm{mol} / \mathrm{l}) \\
\text { Mean } \\
\text { Range }\end{array}$ & $\begin{array}{r}1.82 \\
0.62 \\
\sim 2.70\end{array}$ & $\begin{array}{c}0.33 \\
0.18 \\
\sim 0.66\end{array}$ & $\begin{array}{r}0.29 \\
0.16 \\
\sim 0.58\end{array}$ & $\begin{array}{l}0.28(4) \\
0.12 \\
\sim 0.48\end{array}$ & $\begin{array}{r}0.28 \\
0.09 \\
\sim 0.42\end{array}$ & $\begin{array}{r}0.17 \\
0.08 \\
\sim 0.28\end{array}$ & $\begin{array}{r}0.15 \\
0.05 \\
\sim 0.33\end{array}$ & $\begin{array}{r}0.07 \\
0.04 \\
\sim 0.09\end{array}$ & $\longrightarrow$ \\
\hline $\begin{array}{l}\text { ALA }(\mu \mathrm{mol} / \mathrm{l}) \\
\text { Mean } \\
\text { Range }\end{array}$ & $\begin{array}{r}33 \\
24 \\
\sim 40\end{array}$ & $\begin{array}{r}15 \\
5 \\
\sim 27\end{array}$ & $\begin{array}{r}9 \\
5 \\
\sim 14\end{array}$ & $\longrightarrow$ & $\begin{array}{r}17 \\
9 \\
\sim 24\end{array}$ & $\begin{array}{r}18 \\
8 \\
\sim 23\end{array}$ & $\begin{array}{r}12 \\
5 \\
\sim 21\end{array}$ & $\begin{array}{r}18 \\
11 \\
\sim 28\end{array}$ & $\begin{array}{r}11 \\
4 \\
\sim 15\end{array}$ \\
\hline $\begin{array}{l}\text { Coproporphyrin }(\mu \mathrm{mol} / \mathrm{l}) \\
\text { Mean } \\
\text { Range }\end{array}$ & $\begin{array}{r}0.252 \\
0.063 \\
\sim 0.424\end{array}$ & $\begin{array}{r}0.087 \\
0.023 \\
\sim 0.209\end{array}$ & $\begin{array}{r}0.035 \\
0.014 \\
\sim 0.070\end{array}$ & $\longrightarrow$ & $\begin{array}{r}0.158 \\
0.064 \\
\sim 0.260\end{array}$ & $\begin{array}{r}0.110 \\
0.024 \\
\sim 0.192\end{array}$ & $\begin{array}{r}0.037 \\
0.005 \\
\sim 0.078\end{array}$ & $\begin{array}{r}0.064 \\
0.024 \\
\sim 0.125\end{array}$ & $\begin{array}{r}0.078 \\
0.027 \\
\sim 0.124\end{array}$ \\
\hline $\begin{array}{l}\text { Creatinine (mmol/l) } \\
\text { Mean } \\
\text { Range }\end{array}$ & $\begin{array}{r}17 \cdot 2 \\
5 \cdot 7 \\
\sim 23 \cdot 7\end{array}$ & $\begin{array}{c}8 \cdot 7(4) \\
3 \cdot 1 \\
\sim 20 \cdot 2\end{array}$ & $\begin{array}{l}9 \cdot 0(4) \\
2 \cdot 6 \\
\sim 20 \cdot 8\end{array}$ & $\begin{array}{r}9.8 \\
2.9 \\
\sim 14.9\end{array}$ & - & $\begin{array}{r}10.9 \\
3.8 \\
\sim 18.1\end{array}$ & $\longrightarrow$ & $\begin{array}{r}7 \cdot 2 \\
3 \cdot 4 \\
\sim 13 \cdot 3\end{array}$ & $\begin{array}{r}9.0 \\
4.0 \\
\sim 14 \cdot 1\end{array}$ \\
\hline $\begin{array}{l}\text { Specific gravity } \\
\text { Mean } \\
\text { Range }\end{array}$ & $\begin{array}{r}1.027 \\
1.011 \\
\sim 1.037\end{array}$ & $\begin{array}{r}1.016 \\
1.008 \\
\sim 1.029\end{array}$ & $\begin{array}{r}1.018 \\
1.005 \\
\sim 1.033\end{array}$ & $\begin{array}{r}1.022 \\
1.006 \\
\sim 1.033\end{array}$ & $\begin{array}{r}1.023 \\
1.009 \\
\sim 1.037\end{array}$ & $\begin{array}{r}1.021 \\
1.008 \\
\sim 1.034\end{array}$ & $\begin{array}{r}1.021 \\
1.008 \\
\sim 1.040\end{array}$ & $\begin{array}{r}1.019 \\
1.013 \\
\sim 1.027\end{array}$ & $\begin{array}{r}1.024 \\
1.013 \\
\sim 1.036\end{array}$ \\
\hline $\begin{array}{l}\text { Osmolality }\left(\mathrm{mmol} / \mathrm{kg} \mathrm{H}_{2} \mathrm{O}\right) \\
\text { Mean } \\
\text { Range }\end{array}$ & $\begin{array}{r}871 \\
321 \\
\sim 1291\end{array}$ & $\begin{array}{r}477 \\
215 \\
\sim 880\end{array}$ & $\begin{array}{r}570 \\
310 \\
\sim 950\end{array}$ & $\begin{array}{r}771 \\
218 \\
\sim 1210\end{array}$ & $\begin{array}{r}841 \\
363 \\
\sim 1352\end{array}$ & $\begin{array}{c}743(4) \\
279 \\
\sim 1198\end{array}$ & $\longrightarrow$ & $\begin{array}{r}675 \\
470 \\
\sim 959\end{array}$ & $\begin{array}{c}778(5) \\
582 \\
\sim 1159\end{array}$ \\
\hline $\begin{array}{l}\text { Urinary volume }(1 / 24 \mathrm{hr}) \\
\text { Mean } \\
\text { Range }\end{array}$ & $\begin{array}{r}1.27 \\
0.61 \\
\sim 2.68\end{array}$ & $\begin{array}{r}1.53 \\
0.55 \\
\sim 2.92\end{array}$ & $\begin{array}{r}1.42 \\
0.55 \\
\sim 2.72\end{array}$ & $\begin{array}{r}1.50 \\
0.59 \\
\sim 3.42\end{array}$ & $\begin{array}{r}1.22 \\
0.53 \\
\sim 2.66\end{array}$ & $\begin{array}{r}1.69 \\
0.68 \\
\sim 3.61\end{array}$ & $\begin{array}{r}1.78 \\
0.44 \\
\sim 3.49\end{array}$ & $\begin{array}{r}1.98 \\
0.79 \\
\sim 3.52\end{array}$ & $\begin{array}{r}1.56 \\
0.63 \\
\sim 2.97\end{array}$ \\
\hline
\end{tabular}


Table $2 b$ values calculated by the method of least squares for equation: $\log U=a-b \log V$, and the levels of significance

\begin{tabular}{|c|c|c|c|c|c|c|}
\hline Subject & $\begin{array}{l}\text { Lead } \\
(\mu \mathrm{mol} / \mathrm{l})\end{array}$ & $\begin{array}{l}A L A \\
(\mu \mathrm{mol} / l)\end{array}$ & $\begin{array}{l}\text { Coproporphyrin } \\
(\mu \mathrm{mol} / l)\end{array}$ & $\begin{array}{l}\text { Creatinine } \\
(\mathrm{mmol} / \mathrm{l})\end{array}$ & $\begin{array}{l}\text { Total solutes } \\
(\mathrm{g} / \mathrm{l}) \dagger\end{array}$ & $\begin{array}{l}\text { Total solutes } \\
\left(\mathrm{mmol} / \mathrm{kg} \mathrm{H}_{2} \mathrm{O}\right)\end{array}$ \\
\hline $\begin{array}{l}1 \\
2 \\
3 \\
4 \\
5 \\
6 \\
7 \\
8 \\
9\end{array}$ & $\begin{array}{l}0 \cdot 92^{* *} \\
0 \cdot 64^{*} \\
0 \cdot 76^{* *} \\
0 \cdot 95^{* *} \\
0 \cdot 92^{* *} \\
0 \cdot 50 \\
0 \cdot 88^{* * *} \\
0 \cdot 46^{*} \\
\end{array}$ & $\begin{array}{l}0.33^{*} \\
0.94^{* *} \\
0.65^{*} \\
0.60^{* * *} \\
0.36 \\
0.65^{* * *} \\
0.53^{*} \\
0.73^{*}\end{array}$ & $\begin{array}{l}1 \cdot 11^{*} \\
1 \cdot 21^{*} \\
0.66 \\
\overline{0.80^{* *}} \\
0.93 \\
1.04^{* * *} \\
1 \cdot 16^{* *} \\
0.45\end{array}$ & $\begin{array}{l}0.93^{* * *} \\
1 \cdot 17^{*} \\
1 \cdot 30^{* *} \\
1 \cdot 04^{* * *} \\
0.94^{* *} \\
\overline{0.95 * * *} \\
0.75^{* *}\end{array}$ & $\begin{array}{l}0.72^{* *} \\
0.79 * * \\
1.02^{* *} \\
1.03 * * * \\
0.84^{* * *} \\
0.85^{* *} \\
0.38^{* * *} \\
0.01 \\
0.02 *\end{array}$ & $\begin{array}{l}0.82^{* *} \\
0.82^{* * *} \\
0.68^{* * *} \\
1.03^{* * *} \\
0.80^{* * * *} \\
0.95^{*} \\
0.52^{* *} \\
0.21\end{array}$ \\
\hline Mean & 0.75 & 0.60 & 0.92 & 1.01 & $\left(0 \cdot 63_{\ddagger}^{+}\right)$ & $(0 \cdot 73 \ddagger)$ \\
\hline
\end{tabular}

$U$ is the urinary concentration of the substance examined; $V=$ Urinary volume ( $/$ day); $-=$ Not measured; $\dagger=$ Estimated from specific gravity and Häser's index.

${ }^{*}, * *$, and $* * *=b$ value was significant at the level of $p<0.05, p<0.01$, and $p=0.001$.

$\ddagger=$ Difference in $b$ values among subjects was significant at level of $p<0.05$.
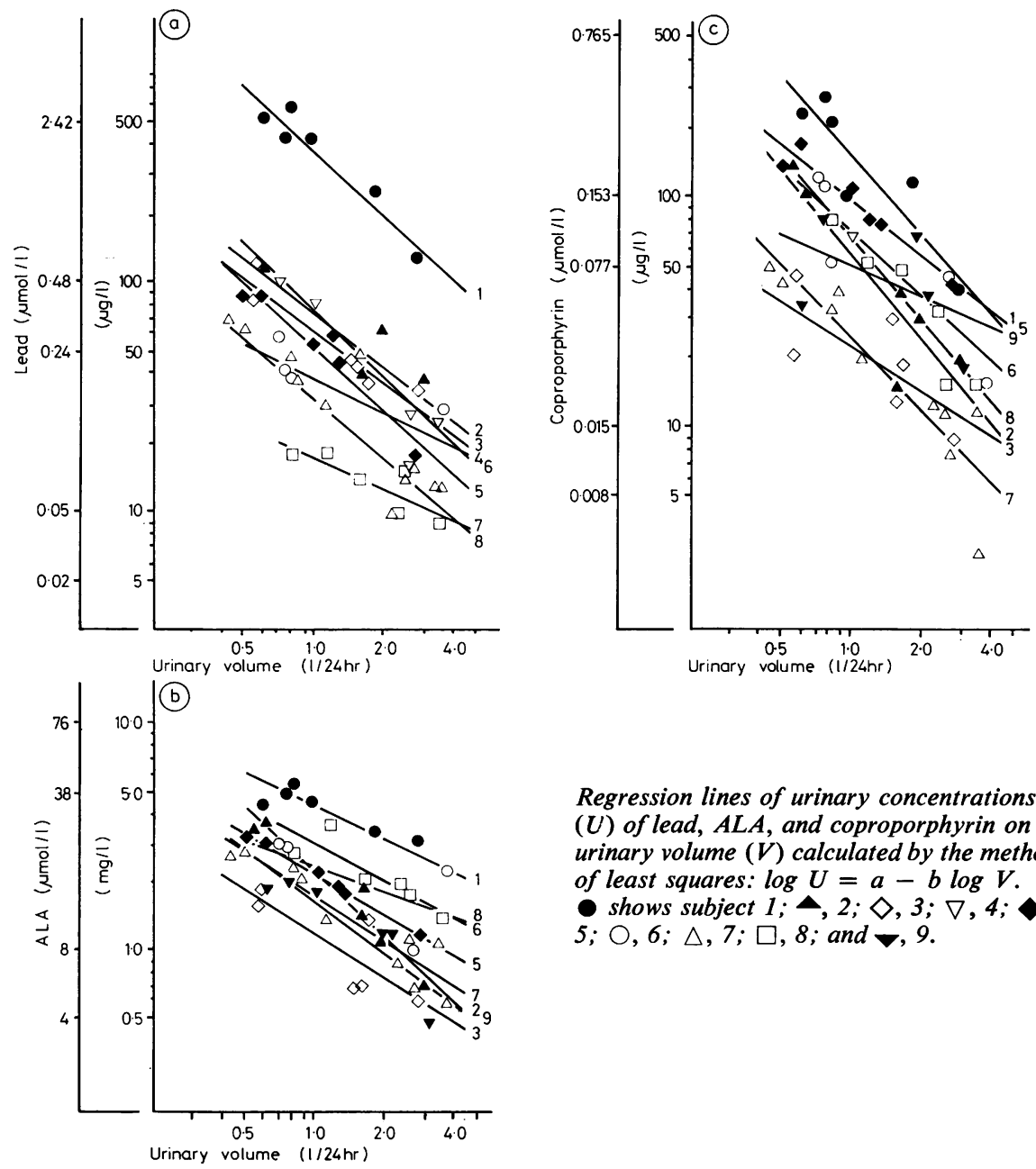

Regression lines of urinary concentrations $(U)$ of lead, $A L A$, and coproporphyrin on urinary volume $(V)$ calculated by the method of least squares: $\log U=a-b \log V$. shows subject $1 ; \Delta, 2 ; \diamond, 3 ; \nabla, 4$; $5 ; \bigcirc, 6 ; \triangle, 7 ; \square, 8$; and $\nabla, 9$. 
Table 3 Matrix of levels of significance for difference in b value (table 2) between two urinary substances

\begin{tabular}{|c|c|c|c|c|c|c|}
\hline & 1 & 2 & 3 & 4 & 5 & 6 \\
\hline $\begin{array}{l}\text { 1) Lead }(\mu \mathrm{mol} / \mathrm{l}) \\
\text { 2) ALA ( } \mu \mathrm{mol} / \mathrm{l}) \\
\text { 3) Coproporphyrin }(\mu \mathrm{mol} / \mathrm{l}) \\
\text { 4) Creatinine }(\mathrm{mmol} / \mathrm{l}) \\
\text { 5) Total solutes }(\mathrm{g} / \mathrm{l}) \dagger \\
\text { 6) Total solutes }\left(\mathrm{mmol} / \mathrm{kg} \mathrm{H}_{2} \mathrm{O}\right)\end{array}$ & & NS & $\begin{array}{l}\text { NS } \\
\text { ( }\end{array}$ & $\begin{array}{l}* * \\
* * * \\
\text { NS }\end{array}$ & $\begin{array}{l}\text { NS } \\
\text { NS } \\
\text { NS } \\
{ }^{*}\end{array}$ & $\begin{array}{c}\text { NS } \\
\text { NS } \\
\text { NS } \\
\text { * } \\
\text { NS }\end{array}$ \\
\hline
\end{tabular}

${ }^{*}=\mathrm{p}<0.05 ;{ }^{* *}=\mathrm{p}<0.02 ;{ }^{* * *}=\mathrm{p}<0.01 ; \mathrm{NS}=\mathrm{p}>0.05 ; \dagger=$ Estimated from specific gravity and Häser's index. Difference is compared by paired comparison using the t-test.

relationships were found between urinary volume and the urinary concentrations on the log scale (table 2 and figure). The equation for this relation was:

$$
\log \mathrm{U}=\mathrm{a}-\mathrm{b} \log \mathrm{V},
$$

where $U$ represents the urinary concentration of the substance examined; V, urinary volume; and b, regression coefficient.

The regression coefficient (b) was significant in all the subjects examined for creatinine; in all but one subject for lead, ALA, total solutes $(\mathrm{g} / \mathrm{l})$, and total solutes $\left(\mathrm{mol} / \mathrm{kg} \mathrm{H}_{2} \mathrm{O}\right)$; and in five subjects for COPRO (table 2). The lack of statistical significance in some cases may be due to the small number of observations, especially in subject 6 . Non-significant differences in the $b$ value among subjects were found for lead, ALA, COPRO, and creatinine (table 2). The mean $b$ value for creatinine was significantly greater than those for lead, ALA, total solutes $(\mathrm{g} / \mathrm{l})$, and total solutes $\left(\mathrm{mol} / \mathrm{kg} \mathrm{H}_{2} \mathrm{O}\right)$ : similarly, the mean for COPRO was greater than that for ALA (tables 2 and 3).

\section{INTRODUCTION OF AN EQUATION TO}

ELIMINATE THE EFFECT OF URINARY VOLUME The equation: $\log U_{i}=a-b \log V_{i}$ was transformed into $U_{i} \cdot V_{i}{ }^{b}=k$, where $i$ represents a sampling number of urine in each subject; and $k$, a constant. Selecting $U_{(V=1)}$ at $V_{i}=1 \mathrm{ml} / \mathrm{min}$, the equation introduced became as follows:

$$
\mathbf{U}_{(\mathrm{V}=1)}=\mathbf{U}_{\mathbf{i}} \cdot \mathbf{V}_{\mathbf{i}} \mathbf{b} \text {, }
$$

where $U_{(V=1)}$ represents the concentration adjusted to one mililitre urinary volume per minute; $U_{i}$, the urinary concentration of the substance examined; and $V_{i}$, observed urinary volume $(\mathrm{ml} / \mathrm{min})$.

When the $b$ value is equal to $1 \cdot 0$, the equation is simplified as $U_{(V=1)}=U_{i} \cdot V_{i}$. This equation means that the timed excretion of a urinary substance ( $\mathrm{mol} / \mathrm{min}$ ) is not affected by urinary volume since $U_{i} \cdot V_{i}$ is equal to the timed excretion of a urinary substance and $U_{(V=1)}$ is a constant in a single subject. When the $b$ value approaches 0 , on the other hand, the equation becomes $U_{i}=a$ constant $\left.\left[U_{v}=1\right)\right]$. In this extreme case the timed excretion varies greatly according to the change of urinary volume since the timed excretion $\left(U_{i} \cdot V_{i}\right)$ is determined by urinary volume $\left(V_{i}\right)$. Thus the $b$ value indicates how much the timed excretion as well as the concentration of urinary substance is affected by urinary volume. In this study, therefore, the timed excretion of lead, ALA, and total solutes was more affected by urinary volume than that of creatinine: similarly, the timed excretion of ALA more than that of COPRO.

\section{Discussion}

Three findings resulted from this study: (1) The relationships between urinary volume and urinary concentrations of lead, ALA, COPRO, creatinine, and total solutes were linear on the log scale. (2) The extent of the effects of urinary volume on urinary concentrations differed between the substancesthat is, between creatinine and in each case lead, ALA, and total solutes; and between COPRO and ALA. (3) An equation: $U_{(V=1)}=U_{i} \cdot V_{i}{ }^{b}$ was introduced to eliminate the effects of urinary volume on urinary concentrations. Further measurements of the $b$ value for other urinary substances would disclose to what extent the urinary concentration and timed excretion of each substance is affected by urinary volume.

To minimise the effects of urinary volume on urinary lead concentrations, three methods have been practised: (1) Collection of 24-h urinary samples. ${ }^{5}$ (2) Calculations of lead excretion as mass of lead per gram of total urinary solutes-that is, concentration adjusted to specific gravity of urine. 6 7 (3) Adjustment to urinary creatinine excretion. ${ }^{8}$ Evidence was found in this study, however, that none of the methods were free from the effect of urinary volume. Firstly, both the total excretion ${ }^{2}$ and the concentration of lead in 24-h urinary samples were affected by urinary volume. Secondly, even the concentrations adjusted to total urinary solutes or 
creatinine would be affected by urinary volume to some extent because of different effects of urinary volume on the concentrations of lead, ALA, COPRO, total solutes, and creatinine: the former three concentrations give a numerator and the latter two a denominator for the calculation of adjusted concentrations. The newly introduced equation, therefore, should be applied because (1) the relationships between urinary volume and urinary concentrations, from which the equation was introduced, were so strong; and (2) the new method directly eliminated the effects of urinary volume.

I thank Miss J Walford, statistician, and Dr D B Douglas, honorary lecturer in occupational medicine at the London School of Hygiene and Tropical Medicine for their counsel. Thanks are also due to Professor T Suzuki, Tohoku University School of Medicine, and Dr K Ushio, director at Tokyo Rosai Hospital, for their valuable suggestions.

\section{References}

${ }^{1}$ Kehoe RA, Cholak J, Hubbard DM, Bambach K, McNary RR, and Story R. Experimental studies on the ingestion of lead compounds. J Ind Hyg Toxicol 1940;22:381-400.

2 Araki S. The effects of water restriction and water loading on urinary excretion of lead, $\delta$-aminolevulinic acid and coproporphyrin. Brit J Ind Med 1978;35:312-17.

${ }^{3}$ Araki S. On the behaviour of 'active deposit of lead (Teisinger)' in Japanese free from occupational exposure to lead. Ind Health (Kawasaki) 1973;11:203-24.

- Wada O, Toyokawa K, Urata G, Yano Y, Nakao K. A simple method for the quantitative analysis of urine delta-aminolevulinic acid to evaluate lead absorption. Brit J Ind Med 1969;26:240-3.

5 Webster SH. Diurnal variation of urinary lead excretion. Public Health Rep 1941;56:1834-48.

- Levine L, Fahy JP. Evaluation of urinary lead determinations, I. The significance of the specific gravity. $J$ Ind Hyg Toxicol 1945;27:217-23.

7 Elkins HB, Pagnotto LD. Is the 24-hour urine sample a fallacy? Am Ind Hyg Assoc J 1965;26:456-60.

8 Molyneux MKB. Use of single urine samples for the assessment of lead absorption. Brit J Ind Med 1964;21: 203-9. 